Impact of Soil and Water Conservation Measures on Soil Erosion Rate and Sediment Yields in a Tropical Watershed in the Central Highlands of Sri Lanka

\author{
Saranga Diyabalanage ${ }^{1}$, K. K. Samarakoon ${ }^{2}$, S. B. Adikari ${ }^{2}$ and Tilak Hewawasam ${ }^{3, *}$ \\ ${ }^{1}$ Department of Natural Resources, Faculty of Applied Sciences, \\ Sabaragamuwa University of Sri Lanka, Belihuloya, Sri Lanka. \\ ${ }^{2}$ Environment and Forest Conservation Division, Mahaweli Authority of Sri Lanka. \\ ${ }^{3}$ Department of Geography, University of Peradeniya, Peradeniya, Sri Lanka. \\ *Corresponding author: tilak@pdn.ac.lk
}




\section{Acknowledgments}

The authors gratefully acknowledge the Environment and Forest Conservation Division, Mahaweli Authority of Sri Lanka for providing permission to conduct this research at their premises with data and facilities. The National Science Foundation of Sri Lanka is thanked for awarding a research grant (RG/2005/DMM/04) to TH. This paper is based on the BSc

thesis conducted by SD at the Department of Natural Resources, Sabaragamuwa University of Sri Lanka. 


\title{
Impact of Soil and Water Conservation Measures on Soil Erosion Rate and Sediment Yields in a Tropical Watershed in the Central Highlands of Sri Lanka
}

\begin{abstract}
The Upper Mahaweli Catchment (UMC) is a very important watershed in the Central Highlands of Sri Lanka since it contains a series of multipurpose reservoirs. Hence, conservation of soil in the UMC should be given the highest priority to reduce sediment yields in streams and to maintain the storage capacities of hydropower reservoirs. The sediment yields measured in the sub-catchments of the UMC before 1995 have revealed that soil erosion is intense in the contributing catchments and siltation in some reservoirs is at an alarming level. The situation in the Upper Uma Oya, a sub-catchment of the UMC, is the worst, reporting the highest sediment yield measured for any catchment in Sri Lanka. Mahaweli Authority of Sri Lanka had embarked on two soil and water conservation projects in the Upper Uma Oya catchment from 1995 to 2005 together with monitoring of sediment yields in the stream. Sediment yield measurements in this catchment revealed that the wash load in the stream had reduced by a factor of five after the implementation of conservation programmes in 1995. Our temporal analyses showed that the role of the other key factors that control soil erosion on a hillslope such as erodibility, slope, erosivity and land use cover is minimal to generate a five-fold reduction in the wash load of the stream. Hence, we report that the conservation measures adopted in the critical areas of the Upper Uma Oya have been very successful and had greatly contributed to the reduction of soil erosion. However, even after conservation, soil erosion rates estimated by stream loads are about 10 times higher than the natural background rate. Hence, as shown in other catchments elsewhere in the world, the ongoing rate of soil erosion can be further lowered by strengthening the existing soil and water management practices together with restoration of vegetation on bare lands.
\end{abstract}

Keywords: Soil erosion, soil conservation, sediment yield, tropical region, trend analysis 


\subsection{Introduction}

Soil erosion is one of the most serious and challenging environmental issues related to land management all over the world. It is a complex natural process altered by anthropogenic activities such as clearing of lands, agricultural practices, surface mining, construction and urbanization. It is reported that seventy five billion metric tons of soil are removed from land annually by wind and water erosion (Pimentel, 1993).Water erosion which accelerated by anthropogenic activities is the key process that has been taking place in humid and tropical regions. The detached sediments from hillslopes by sheet, rill and gully erosion are exported to the river systems, a significant portion of that is silted into many inland reservoirs, and the rest is being transferred to the ocean. Many studies have revealed that sediment loads in the rivers of Asia have been rapidly increasing as a result of increased rate of inland soil erosion. Increasing pressure on land and fragile ecosystems by rapidly growing population is the main reason for accelerated soil erosion. Such erosion has negatively impacted on the environment by various means; e.g. reducing the soil fertility of arable lands (Pimentel, 2001, Lal, 2003), increasing siltation in inland reservoirs (Krasa et al., 2005) and increasing risk of flash flooding in lowlands (Olive and Rieger, 1992, Yin and Li, 2001). Therefore, rivers should be monitored for suspended sediment concentrations, even though it incurs extensive labour and time, in order to understand soil erosion losses in contributing catchments and also to study the sediment transport pattern in rivers. Transportation of suspended sediments in rivers is very complex, non-linear, dynamic and widely scattered due to the influence of physical processes involved and variability in space and time. Therefore, studying the behaviour of suspended sediment transportation in rivers is also an elusive task in hydrology (Shang and Kamae, 2005; Illangasinghe and Hewawasam, 2015). Similarly, estimation of suspended sediment loads in rivers is a major concern since information on sediment loads of rivers can be used for many studies such as evaluation of contaminant transport, reservoir sedimentation, environmental impact assessment, sediment transport to oceans, channel and harbour siltation, soil erosion and ecological impacts (Horowitz, 2003; Syvitski et al, 2000).

Sri Lanka is a tropical country, rich in water resources with a large number of rivers, most of them originating in the Central Highlands. The Upper Mahaweli Catchment (UMC) covering about $15 \%$ of land in the country is the most important watershed in Sri Lanka due to its size and economic importance (Hewavisenthi, 1997; Gunatilake and Vieth, 2000).The prevailing climatic conditions and topography of the land have created excellent conditions well-suited 
1 for generation of hydropower (Hewawasam, 2010). Accelerated Mahaweli Development

2 Programme implemented in 1975, is one of the major development programmes ever 3 implemented in Sri Lanka aimed at constructing a series of reservoirs across Mahaweli River 4 for hydropower generation and diversion of water to the dry zone of the country for 5 irrigation. At present, UMC consists of four major sub-catchments of Kothmale, Victoria, 6 Randenigala and Rantambe that feed five reservoirs and one diversion pond (Figure 1). These 7 reservoirs generate about 58\% of electricity in the country (Statistical Digest, Ceylon 8 Electricity Board, Sri Lanka, 2013), and irrigate $3000 \mathrm{~km}^{2}$ of agricultural lands (Gamage and

Soil erosion is a long-standing problem in the UMC where a major portion of the area is used for cultivation practices causing severe erosion. The sediment monitoring programs conducted in the UMC have revealed that soil erosion within the watershed is intense. Findings of many studies revealed that sedimentation in major reservoirs is increasing at an alarming rate. Most of the reservoirs have dropped their original capacity within a short period of time after impoundment. Sediment monitoring programmes of sub catchments of the UMC showed that the situation in the Upper Uma Oya Catchment is the worst reporting about $1400 \mathrm{t} \mathrm{km}^{-2}$ of mean sediments per rainy season (Rajapakse, 1998), which is the highest yield recorded for a catchment in Sri Lanka. In the same catchment, local rates of soil loss from agricultural plots have been reported as high as $7000 \mathrm{t} \mathrm{km}^{-2} \mathrm{y}^{-1}$ (Gunatilake and Vieth, 2000, Hewawasam and Illangasinghe, 2015). This rate of soil loss is approximately 100 times greater than the soil production rates within the catchment as measured by in-situ produced cosmogenic nuclides (Hewawasam et al., 2003). It is believed that this situation is mainly due to the inappropriate landuse pattern and intensive cultivation practices. In the Upper Uma Oya catchment, a large area of land is utilized for upland annual crops like vegetables, potato and other crops even though most of the areas are not suitable for annual crops due to steepness of land. Two major projects, Upper Mahaweli Watershed Management Project (UMWMP) and Upper Watershed Management Project (UWMP), have been put in place in the UMC from 1995 to 1997 and from 1998 to 2005, respectively by the Mahaweli Authority of Sri Lanka (MASL) with the intention of soil and water conservation. Therefore, it has become very relevant to evaluate the success of soil and water conservation measures applied in this watershed. Hence, the scope of this study was to assess the effectiveness of soil and 
water conservation strategies with the aid of actually measured sediment loads in the stream at two stages; before and during the conservation projects. To our knowledge, this is the first systematic approach of evaluating the effectiveness of soil and water conservation measures in an agricultural catchment in Sri Lanka by actually using quantified stream load data.

\subsection{Study Area}

Uma Oya is one of the main tributaries within the UMC (Figure 1), which flows into Rantambe Reservoir. The Upper Uma Oya catchment of the UMC covers approximately 98 $\mathrm{km}^{2}$ of surface having a diverse spatial pattern of land use (Figure 2), topography (Figure 3) and rainfall (Figure 4). Topography of the catchment is very complex and the elevation ranges from $900 \mathrm{~m}$ to $2400 \mathrm{~m}$ and the upper part has highly variable topography compared to the lower part (Figure 3). Climatic condition of the catchment area varies considerably and the average annual rainfall ranges from $2000 \mathrm{~mm}$ to $2500 \mathrm{~mm}$. The main rainy season is from November to January due to the north-east monsoon. Average annual temperature ranges from 16 to $29{ }^{\circ} \mathrm{C}$ with minimum and maximum mean temperatures recorded in January and April respectively. The upper catchment area is in the Wet Zone and the lower area belongs to the Intermediate Zone, of the three climatic zones of Sri Lanka. Rainfall in the area are being monitored at six gauging stations located at Ambewela, Hakgala Botanical Garden, Kirklees Estate, Lellopitiya Estate, Nuwara Eliya and Welimada Group all of which are in close proximity of the catchment. The data collected from these stations were used to observe the spatial distribution of rainfall pattern within the catchment (Figure 4) and it disclosed that the upper part of the catchment receive higher rainfall compared to the lower part. Furthermore, the rainfall data suggest that the catchment receive water from both monsoon and inter-monsoon seasons. Average rainfall of $495 \mathrm{~mm}$ per season can be observed in the North East Monsoon that prevails from December to February of the following year. Though the South West Monsoon that prevails from May to September contributes an average rainfall of $720 \mathrm{~mm}$ per season, low rainfall can be observed in June-July period. In addition, second inter-monsoon from October to November, is the highest contributor which provides nearly $511 \mathrm{~mm}$ rainfall per season and particularly low rainfall can be observed in the first intermonsoon (March-April) that accounts for $287 \mathrm{~mm}$ per season.

Geologically, the area belongs to the Highland Complex, one of the major litho-tectonic divisions of the country, comprising of crystalline metamorphic rocks such as garnetsillimanite-biotite gneiss and charnockitic gneiss. Scattered bands of marble and quartzite are 
visible in some parts of the study area. Main soil type of the area is Red Yellow Podsollic soil. The lower part of the valley in the catchment is under paddy cultivation whereas many gently-sloping to steeply sloping lands are under potato and vegetables even at the highest elevations. The upper part of the catchment area is covered with natural forest and tea plantations (Figures 2 and 3). Most of the hill tops in the area are without any tree cover due to pressure on land for cultivation (Table 1).

\section{Soil Conservation and Water Management in the Upper Uma Oya Catchment}

Since rates of sediment yields were found to be extremely high in the UMC, two major projects were initiated in order to conserve soil and water resources with special emphasis on the Upper Uma Oya catchment. Both projects were integrated as community-participatory projects and conservation was carried out by disseminating technical knowledge through awareness programmes. In April 1995, Sri Lankan-German Upper Mahaweli Watershed Management Project (UMWMP) was initiated as a three-year soil and water conservation programme in Welimada and Uvaparanagama Divisions of Badulla District to promote conservation measures to minimize soil erosion (Makadawara, 1998). In these areas, over $95 \%$ of the adult population depends on agriculture and their primary source of income is potato and vegetable cultivation. Under the UMWMP, planting Vetiver (Vetiver zezanoides) and grass strips have been introduced as agronomic conservation measures. During the project period, nearly $8-10 \mathrm{~km}^{2}$ of the total land area was conserved by growing Vetiver (ca. 4-6 $\mathrm{km}^{2}$ ) and grass stripes (ca. $1.5-2 \mathrm{~km}^{2}$ ) specifically in the farming areas. Other than that, on-farm mechanical conservation measures such as stone terraces, bunds and drain lines were implemented in ca. 2-4\% of the total land area. Furthermore, as off-farm conservation measures, gullies were reconstructed by making bunds in most critical areas (Makadawara, 1998). Approximately $5 \%$ to $10 \%$ of the Upper Uma Oya catchment had been covered under this conservation project (Diyabalanage, 2013).

Table 1 Different land use types in the Upper Uma Oya catchment in 1999 (Source: Environmental and Forest Conservation Division, Mahaweli Authority of Sri Lanka)

\begin{tabular}{|l|r|r|}
\hline \multicolumn{1}{|c|}{ Land Use Type } & Area $\mathbf{( k m}^{\mathbf{2}} \mathbf{)}$ & \multicolumn{1}{c|}{ Area \% } \\
\hline Annual rainfed crops & 13.85 & 14 \\
\hline Kandyan Forest Gardens & 6.87 & 7 \\
\hline Mixed Forests & 0.82 & 1 \\
\hline Natural Forest & 25.27 & 26 \\
\hline
\end{tabular}




\begin{tabular}{|l|r|r|}
\hline Non Agricultural Lands & 0.13 & $<1$ \\
\hline Paddy & 5.75 & 6 \\
\hline Plantations & 8.42 & 9 \\
\hline Rock outcrops & 0.19 & $<1$ \\
\hline Scrub and grasslands & 3.76 & 4 \\
\hline Settlements & 0.43 & $<1$ \\
\hline Tea & 16.00 & 17 \\
\hline Urban Areas & 1.03 & 1 \\
\hline Vegetables & 13.89 & 14 \\
\hline Water bodies & 0.59 & 1 \\
\hline
\end{tabular}

2 The Upper Watershed Management Project (UWMP) was designed with the consultancy of 3 Norwegian Consortium for Development and Environment, and Lanka Environment and 4 Development Services, to assist the Government in addressing forest and degradation 5 problems in four watersheds of Sri Lanka that included Kalu Ganga, Walawe Ganga, Kirindi 6 Oya, and Uma Oya. The project was initiated with the assistance of Asian Development Bank 7 (ADB) and was planned to improve soil conditions by introducing measures to control soil 8 erosion and sedimentation. The project was a farmer-led integrated watershed management 9 programme to improve the knowledge and activities towards environmental conservation at household level and improvement of sustainable farming systems. Under the UWMP, establishing mechanical soil conservation structures, land preparation to minimize soil erosion such as reverse sloping beds, sloping agricultural land technology (SALT), contour strips planting with vetiver/grass and terracing were introduced as on-farm conservation activities. During the project period, SALT and buffer zone planting were introduced within the catchment covering an approximate area of $2-2.5 \mathrm{~km}^{2}$ and $8-10 \mathrm{~km}^{2}$, respectively (Overall Progress Report, UWMP, 2006). Apart from that contour strip planting with vegetable cover crops and Vetiver and grass strips were implemented as agronomic soil conservation measures. Mechanical conservation measures such as stone terraces and bunds were constructed in most of the agricultural areas with an extent of ca.30 $\mathrm{km}^{2}$. Hence, about $30-$ $35 \%$ of the land area was conserved by on-farm soil conservation (D.P. Munaweera, personal communication). Under off-farm soil conservation, engineering structures were constructed in order to control surface drain water velocity and its flow. During the project period, check dams, leader drains, lock and spills were constructed and in critical areas gullies were reconstructed with bunds. Stream reservation was also applied as a conservation measure and badly constructed 
irrigation cannels were reconstructed to mitigate the risk in natural hazards that may occur due to seeping of water into the ground water table (Diyabalanage 2013, D.P. Munaweera, personal communication) (Figure 4). In this project, an average of Rs 26,081.00 has been spent per hectare to achieve above targets (Jayaweera et al, 2004). Approximately $40 \%$ of the Upper Uma Oya catchment was conserved by the project.

\section{Measurement of Suspended Sediment Loads in the Upper Uma Oya Catchment}

Suspended sediment concentration has been measured by using the pump sampling technique developed by the HR Wallingford, United Kingdom in a six small catchments $\left(50-100 \mathrm{~km}^{2}\right)$ of the UMC. Monitoring of the suspended sediment concentration was carried out for 12 consecutive years in the Upper Uma Oya catchment by the Environment and Forest Conservation Division of the Mahaweli Authority of Sri Lanka. Sediment measurements were conducted in three verticals depending on the way the water flow (and hence sediment) is concentrated towards one bank or the other (Figure 6). Samples had been pumped from selected three depths in each vertical. If the depth of the flow is less than $0.3 \mathrm{~m}$, two samples were taken at $0.05 \mathrm{~m}$ and $0.2 \mathrm{~m}$ intervals above the bed. If the depth of the flow is more than $0.3 \mathrm{~m}$, but less than $0.4 \mathrm{~m}$ three samples were taken at $0.05 \mathrm{~m}, 0.2 \mathrm{~m}$ and $0.3 \mathrm{~m}$ levels above the bed accordingly. If the depth is greater than $0.4 \mathrm{~m}$, three samples were taken at $0.05,0.3 \mathrm{x}$ $\mathrm{D}$ and $0.6 \mathrm{x} \mathrm{D}$ where $\mathrm{D}$ is the depth of the water flow. Sediment and water mixture were pumped and allowed to pass through a 63 micron sieve. The sediment that passes through the sieve was collected in a graduated container that measures the volume of pumped sediment. Sediment retained in the sieve (sand) and the filtered water containing the particles less than 63 micron (silt and clay, called as wash load) were transported into the laboratory where they were oven-dried and weighed to calculate their concentrations (Diyabalanage, 2013).

In order to measure the stream discharge, current metering was carried out. Width of the river was measured and then was divided into segments with equal top width. Velocity of the water flow in each segment was measured at the depths of $0.2 \mathrm{D}$ and $0.8 \mathrm{D}$ segment from the surface where $\mathrm{D}$ is the height of the water column from the stream bed to surface of the water level. The width of water flow at the point of measurement has varied from $0.75 \mathrm{~m}$ to $9.5 \mathrm{~m}$ and number of segments used varied depending on the stream width. In general, the width of each segment varied from $0.35 \mathrm{~m}$ to $0.5 \mathrm{~m}$ and the maximum number of segments used was 20. Mean velocity was calculated and the discharge through a segment was calculated by 
1 using the equation of $Q^{n}=V^{n} A^{n}$, where $Q^{n}$ is flow through segment $n\left(m^{3} s^{-1}\right), V^{n}$ is mean velocity of segment $n\left(\mathrm{~ms}^{-1}\right)$ and $A^{n}$ is cross section area of segment $n\left(m^{2}\right)$.

3 Following the above method, the suspended load concentration and discharge of the Upper Uma Oya catchment were measured for a period of 12 years from 1994 to 2005. Even though the suspended load transport pattern in a stream is very complex, this method provided the best estimates of suspended load data for a period of 12 years, probably the most reliable and the longest record of experimental suspended load measurements for a catchment in Sri Lanka. Therefore, in this research, we attempt to analyse the temporal variation of suspended loads in the Upper Uma Oya referring to the factors that determine the rate of soil erosion within the catchment.

\section{Results and Discussion}

Rainfall, discharge, sum of clay and silt content of the suspended load (referred to as wash load hereafter), and sand content in the suspended load monitored over the period of 12 years from 1994 to 2005 in the Upper Uma Oya catchment are presented in Table 2. These data indicate that, on average, 70-90\% of the total suspended sediment is wash load (Table 2), which is predominant in the suspended load. Therefore, our analysis on changing suspended load with time is primarily focused only on wash load data. In 1993 to 1995, the annual wash load was measured as high as $2463 \mathrm{t} \mathrm{km}^{-2} \mathrm{y}^{-1}$, but it has reduced to an average value of $530 \mathrm{t}$ $\mathrm{km}^{-2} \mathrm{y}^{-1}$ for the period from 1995 to 2005. This indicates that an average of five fold reduction of wash load in the stream had occurred in the Upper Uma Oya catchment from 1995 to 2005 (Figure 7).The sand fraction in the suspended load also shows the same reducing trend from 1995 but its magnitude is not as large as wash load (Figure 7). However, there is a considerable increase of wash and sand loads in the 1997/1998 hydrological year even after implementing the conservation treatments in the catchment (Figure 7). This is the period of termination of activities of one conservation project and then switching to another project was performed. Seemingly, during this transition from the UMWM project to the UWM project, conservation measures may have not been properly monitored as evident in the sediment load measurements.

The double mass plot of the cumulative suspended sediment yield versus discharge can also be used to visualize the trend of the sediment flux relative to that of water discharge (Figure 8 (a)). If the sediment flux and runoff indicate similar trends, the slope of the double mass plot will not change. But, if the sediment loads increase or decrease at a greater rate than the 
annual runoff, the double mass plot will indicate a departure from its original slope (Walling, 2003). Before 1996, the slope of the double mass plot does not show any significant departure from its original slope. But after 1996, the slope of the trend line began to decrease, which indicates a great reduction of sediment yield inferring a decrease of soil erosion in the upstream catchment. Therefore, it is important to understand the contribution of controlling factors that moderate the rate of soil erosion within the Upper Uma Oya.

Seasonal variation of the rainfall pattern discloses that the catchment receives rainfall in both monsoon and inter-monsoon seasons and, hence it is difficult to segregate the rainfall pattern within the catchment as high and low rainfall categories in six-monthly periods. Therefore, a comparison in the suspended sediment loads were carried out considering three months of high (from October to December) and low (from February to April) rainfall periods. Average rainfall and discharge in the high rainy period was $233 \mathrm{~mm}$ per month and $8 \times 10^{6} \mathrm{~m}^{3} \mathrm{~s}^{-1}$ per month. In contrast, average rainfall and discharge in the low rainfall period were $136 \mathrm{~mm}$ per month and $4.4 \times 10^{6} \mathrm{~m}^{3} \mathrm{~s}^{-1}$ per month, respectively. Before the period of soil and water conservation, the average suspended sediment load in the high and low rainfall periods were $370 \mathrm{t} \mathrm{km}^{-2}$ per month and $35 \mathrm{t} \mathrm{km}^{-2}$ per month, respectively. However, during the period of soil and water conservation, the average suspended sediment load has significantly reduced as $145 \mathrm{t} \mathrm{km}^{-2}$ per month in the high and $22 \mathrm{t} \mathrm{km}^{-2}$ per month in high and low rainfall periods, respectively. It is important to highlight that the sediment loads in the stream has reduced by a factor of 2-3 in rainy months due to the soil and water conservation practices. Hence, it is possible to conclude that the conservation programmes are very effective in the rainy seasons.

Table 2 Discharge, rainfall and sediment yields in the Upper Uma Oya catchment, Sri Lanka for 12 hydrological years. Suspended load is presented in two components as sand load and silt load. Unmeasured bed load was taken to be $10 \%$ of the total suspended load.

\begin{tabular}{|c|r|r|r|r|r|r|r|}
\hline $\begin{array}{c}\text { Hydro. } \\
\text { Year }\end{array}$ & $\begin{array}{c}\text { Discharge } \\
\left(10^{6} \mathrm{~m}^{3} \mathrm{~s}^{-1}\right)\end{array}$ & $\begin{array}{c}\text { Rainfall } \\
(\mathrm{mm})\end{array}$ & $\begin{array}{c}\text { Sand } \\
\text { load } \\
(\mathrm{t})\end{array}$ & \multicolumn{1}{|c|}{$\begin{array}{c}\text { Silt } \\
\mathrm{load} \\
(\mathrm{t})\end{array}$} & $\begin{array}{c}\text { Additional } \\
\text { bed load } \\
(\mathrm{t})\end{array}$ & $\begin{array}{c}\text { Total } \\
\text { load } \\
(\mathrm{t})\end{array}$ & $\begin{array}{r}\text { Sediment } \\
\text { Sp. Yield } \\
\left(\mathrm{t} \mathrm{km}^{-2}\right)\end{array}$ \\
\hline $1993 / 1994$ & 83.2 & 1817 & 48620 & 293142 & 34176 & 375938 & 3822 \\
\hline $1994 / 1995$ & 77.8 & 2120 & 22353 & 149987 & 17234 & 189574 & 1928 \\
\hline $1995 / 1996$ & 48.9 & 2144 & 3891 & 25299 & 2919 & 32109 & 326 \\
\hline $1996 / 1997$ & 35.1 & 1651 & 5351 & 33497 & 3885 & 42733 & 435 \\
\hline $1997 / 1998$ & 65.2 & 2392 & 26626 & 168605 & 19523 & 214754 & 2184 \\
\hline $1998 / 1999$ & 45.4 & 2449 & 6052 & 70160 & 7621 & 83834 & 852 \\
\hline $1999 / 2000$ & 67.0 & 2156 & 12983 & 40077 & 5306 & 58366 & 593 \\
\hline
\end{tabular}




\begin{tabular}{|r|r|r|r|r|r|r|r|}
\hline $2000 / 2001$ & 48.2 & 1844 & 8634 & 14521 & 2316 & 25471 & 259 \\
\hline $2001 / 2002$ & 45.7 & 1766 & 19973 & 71039 & 9101 & 100113 & 1018 \\
\hline $2002 / 2003$ & 61.3 & 2286 & 13750 & 27980 & 4173 & 45903 & 467 \\
\hline $2003 / 2004$ & 39.2 & 1626 & 2780 & 7870 & 1065 & 11715 & 119 \\
\hline $2004 / 2005$ & 101.6 & 1898 & 23270 & 38190 & 6146 & 67606 & 687 \\
\hline
\end{tabular}

1 Soil erodibility, steepness of the slope, erosivity, land use cover and cropping management,

are the key factors that determine the rate of soil erosion in a catchment. Therefore, these factors are widely used in erosional models such as Universal Soil Loss Equation (USLE), Honda model, CORINE model, in order to asses risk of soil erosion. Soil erodibility defines the susceptibility of the soil to detachment and transport triggered by raindrops and runoff. This factor is mainly related to the soil properties, namely texture, structure, organic matter content and permeability (Kirkby et al. 2000). The change of soil erodibility in the Upper Uma Oya catchment within a period of 12 years, where the suspended loads were quantitatively measured, is insignificant; hence the large decrease of wash load in the stream after 1994 is not likely to be caused by change in soil erodibility. As many studies have proved, slope has an important influence in controlling erosion rates. For an example, it was shown that soil loss increases exponentially with the degree of slope (Bruce-Okine and Lal, 1975). Ebisemiju (1988) also showed that slope gradient alone explains about $63 \%$ of the spatial variation of intensity of gully erosion. Therefore, slope is one of the most important determinants of soil erosion, especially when it exceeds a critical angle. In our study, the slope layer of the study area was produced by using DEM with a resolution of $10 \mathrm{~m}$. When the slope and land use layers of the Upper Uma Oya are overlaid (Figures 2 and 3), it is very clear that steep slopes are dominantly covered by annual rain-fed crops and vegetables (Figure 9). Particularly, the annual rain-fed crops exist in the slopes where the angle percentage is $>32 \%$. Therefore, according to slope and land use pattern, this terrain is highly vulnerable to soil erosion, which was also evident by the measured suspended loads in the stream (Figure 9). Hillslopes are developed by geomorphological processes over long periods of time, which is a geological process even though human inferences have also become important over the recent years. Therefore, the steepness of the slopes cannot be changed abruptly over a period of 12 years during the period of suspended sediment load monitoring. Therefore, the temporal variation in the wash load, that is visible over 12 years, cannot be accounted by a change in the steepness of the slope.

The erosivity quantifies the effect of rainfall impact and also reflects the amount and rate of runoff that is also to be associated with precipitation events. If a precipitation has reduced, it 
1 minimises the rain-splash and runoff detachment on the hillslopes resulting in a low wash

2 load in the streams. On the other hand, if rainfall has increased, the situation is opposite. The 3 rainfall can be changed even over a period of short term; hence it is imperative to analyse the trend of precipitation pattern in this catchment from 1994 to 2005 to disclose its effect on reduction of wash load amount in the stream. The precipitation data available for six rainfall stations (Ambewela, Hakgala Botanical Garden, Kirklees Estate, Lellopitiya Estate, Nuwara Eliya, Welimada Group) close to the river load gauging station were studied by MannKendall statistics and Sen's slope estimator to observe the trend in the precipitation. MannKendall test which is a non-parametric statistical procedure introduced by Mann (1945) and Kendall (1975) was applied to the annual rainfall data to verify the increasing or decreasing trends of the parameters. The Mann-Kendall statistic (S) defined as,

$S=\sum_{i=1}^{n-1} \sum_{j=i+1}^{n} \operatorname{sgn}\left(x_{j}-x_{i}\right)$

Where, $x_{j}$ are the sequential data values, $\mathrm{n}$ is the length of the data set and,

$\operatorname{sgn}\left(x_{j}-x_{i}\right)=\left\{\begin{array}{c}+1 \ldots \text { if }\left(x_{j}-x_{i}\right)>0 \\ 0 \ldots \text { if }\left(x_{j}-x_{i}\right)=0 \\ -1 \ldots \text { if }\left(x_{j}-x_{i}\right)<0\end{array}\right.$

When $\mathrm{n} \geq 8$ the statistic $\mathrm{S}$ is approximately normally distributed with the mean $\mathrm{E}(\mathrm{S})=0$ and variance as,

$\operatorname{Var}(S)=\frac{1}{18}\left[n(n-1)(2 n+5)-\sum_{i=1}^{m} t_{i}\left(t_{i}-1\right)\left(2 t_{i}+5\right)\right]$

Where $\mathrm{m}$ is the number of tied groups and $t_{i}$ is the size of the $\mathrm{i}^{\text {th }}$ tied group. The standardized test statistic $\mathrm{Z}$ is calculated by,

$$
Z=\left\{\begin{array}{l}
\frac{S-1}{\sqrt{\operatorname{Var}(S)}} \ldots \text { if } S>0 \\
0 \quad \ldots \text { if } S=0 \\
\frac{S+1}{\sqrt{\operatorname{Var}(S)}} \ldots \text { if } S<0
\end{array}\right.
$$

$\mathrm{Z}$ follows a standard normal distribution and a positive value signifies an upward trend whereas negative value signifies a downward trend. A significance level $\alpha$ is also utilized for testing either an upward or downward monotone trend (two-tailed test). If the computed $\mathrm{Z}$ value is negative and computed probability is greater than the level of significance $(\alpha)$ the 
trend is considered as negative whereas if the $\mathrm{Z}$ value is positive and computed probability is greater than the level of significance $(\alpha)$ the trend is considered as positive.

Sen's slope estimator, which is also a non-parametric test developed by Sen (1968), was also applied to estimate the true slope of the Mann-Kendall trend analysis. Sen's estimator is first calculated as,

$Q_{i}=\frac{\left(x_{j}-x_{k}\right)}{(j-k)} \quad i=1 \ldots N$

Where $x_{j}$ and $x_{k}$ are data values of times $j$ and $k,(j>k)$ respectively. The median of the $\mathrm{N}$ values of $Q_{i}$ is represented as Sen's estimator of slope and computed as $Q_{m e d}=Q_{(N+1) / 2}$ if $\mathrm{N}$ appears odd, and it is considered as $Q_{m e d}=\left(\frac{1}{2}\right)\left(Q_{\frac{N}{2}}+\frac{Q_{\frac{N+2}{2}}}{2}\right.$ if $\mathrm{N}$ appears even. Then $Q_{m e d}$ is computed by a two tailed test at $100(1-\alpha) \%$ confidence interval and true slope can be obtained by the non-parametric test.

Kahya and Kalayci (2004) noted that under Mann-Kendall statistic (S), a positive value in S indicates an increasing trend whereas a negative value indicates a decreasing trend. The strength of the trend corresponds to the magnitude of the $S$ value. The Figure 10 illustrates the average monthly rainfall for 12 years with maximum rainfall occurrence in the year 1999 with the total rainfall of $2449 \mathrm{~mm}$ and minimum rainfall in the year 2004 with total rainfall of $1626 \mathrm{~mm}$. Average rainfall during the study period was $2012 \pm 283 \mathrm{~mm}$. Trend in rainfall pattern for the study period was calculated using Mann-Kendall test and it revealed that there was no trend ( $\mathrm{p}=0.84$ at $95 \%$ confidence level) (Table 3). Sen's slopes estimator was also employed to figure out the change per unit time of trend observed in all rainfall time series. Positive sign of the $\mathrm{Q}$ value indicates an upward slope whereas negative sign represents a downward slope. $\mathrm{Q}$ was resulted as $-12.7 \mathrm{~mm} /$ year which confirms the trend is not significant (Table 3). This proves that the rainfall pattern has not changed significantly throughout the suspended load monitoring and the observed 5-fold reduction in wash load in the UOC is not due to the reduction of erosivity over the long-term time scale. Absence of significant change in rainfall suggests that the natural land use cover has also not changed during this short period of study to cause a five-fold reduction in wash load. Based on the preceding explanation, the implemented measures of soil and water conservation within the catchment are largely accountable for the enormous reduction of wash load in the stream since 1995. In summary, we conclude that the wash loads in the stream and spatially-averaged soil erosion rates in the Upper Uma Oya catchment have decreased by a factor of five after implementing 
the large-scale soil and water conservation projects and the employed measures are found to be effective. Spatially-averaged background erosion rate, which is the rate of natural erosion that is driven by geological and climatic agents further than human interferences, for the same catchment has been measured as $58 \mathrm{t} \mathrm{km}^{2} \mathrm{y}^{-1}$ by using cosmegenic ${ }^{10} \mathrm{Be}$ concentrations in fluvial sediments (Hewawasam et al, 2003).We can now compare the background rates with the recent soil erosion rates deduced for the Uma Oya catchment before and after the conservation. Before conservation, the soil erosion rates intensified by humans are 43 times greater than the natural background rates. Importantly, after the conservation, the soil erosion rates averaged for 10 years (from 1995 to 2005) is only 9 times greater than the natural background rates. In some years, for examples in 2000 and 2003, the soil erosion rates are only 4-6 times greater than the natural background rate. Therefore, this comparison highlights how the soil erosion rates have dramatically decreased as a result of employing a soil and water conservation programme systematically in croplands of a rugged catchment. It was revealed that accelerated soil erosion in croplands can be dropped even to the natural background levels by successful restoration of dense vegetation, regardless of whether the type of vegetation is native or anthropogenic, as illustrated in the southern Ecuadorian Andes (Vanacker et al, 2007). However, the Upper Uma Oya catchment is not yet considered for a large scale reforestation programme even though the croplands are maintained by applying soil and water management measurers. Therefore, introducing of reforestation, perhaps to the abandoned tea estates in the steep slopes of the catchment, together with soil and water management in the croplands will further improve the status of the catchment by decreasing soil erosion that leads to reduction of siltation in downstream hydropower reservoirs.

Table 3. Annual rainfall and discharge trends in UOC over 12 year period using the MannKendall test and Sen's slope estimator method.

\begin{tabular}{lccccccc}
\hline Parameter & \multicolumn{4}{c}{ Mann-Kendall Test } & & $\begin{array}{c}\text { Sen's } \\
\text { slope }\end{array}$ & $\begin{array}{c}\text { Trend (at 95\% level } \\
\text { of significance) }\end{array}$ \\
\cline { 2 - 8 } & First & Last & $\mathrm{n}$ & $\begin{array}{c}\text { Kendall- } \\
\text { tau }\end{array}$ & p-value & $\mathrm{Q}_{\mathrm{i}}$ & \\
& year & year & & & & \\
\hline Rainfall & $93 / 94$ & $04 / 05$ & 12 & -0.06 & 0.84 & -12.7 & No Trend \\
Discharge & $93 / 94$ & $04 / 05$ & 12 & -0.15 & 0.55 & -1.2 & No Trend \\
\hline
\end{tabular}


1 When the wash load (silt plus clay) and the sand fraction of the suspended loads are compared, the reduction of wash load in the stream after conservation is more significant than the reduction of sand fraction (Figure 7). In the Upper Mahaweli catchment, soil and water management measures have been applied only on the hillslopes and little attention has been paid to conserve the stream bank and the bed. Therefore, it can be suggested that these two loads may have two different sources of origin, i.e. silt and clay fractions may have mainly derived from hillslopes by sheet, rill and gully erosion, and greatly reduced after the conservation whereas sand particles may have dominantly generated by erosion of stream banks and stream beds. This is just a suggestion and needs to be verified by a detailed study which is not the focus of this paper.

\section{Conclusions}

Suspended sediment loads measured at the Welimada gauging station of the Upper Uma Oya catchment of the UMC during a period of 12 years from 1994 to 2005 showed that around $70-90 \%$ of the suspended load in the stream contains silt and clay-sized particles and they are transported as the wash load. Double mass plot of the cumulative suspended sediment load vs discharge indicates a downward trend of the suspended load in the stream relative to the discharge after 1995. This is an indication of reducing the rate of soil erosion in the catchment at considerable level over a period of 10 years. The change in soil erodibility, steepness of the slope and land use cover have likely not changed over a period of 12 years to reduce the wash load in the stream by a factor of five. Trend of annual rainfall for the period from 1994 to 2005 as analysed by two statistical tests of Mann-Kendall and Sen Methods is not significant; hence the erosivity has also not affected over a long-term scale for the reduction of soil erosion in the catchment. Therefore, it is evident that such a five-fold reduction in wash load in the Upper Uma Oya catchment is clearly attributed to the success of cropping management practices that was conducted by soil and water conservation. In summary, we conclude that the wash load in the Upper Uma Oya catchment has decreased by a factor of 5 after 1995 with the introduction of two systematic soil and water management programmes highlighting the effectiveness of conservation measures. However, the spatiallyaveraged erosion rate of the Upper Uma Oya catchment even after the conservation is about 10 times greater than the natural background rate. Therefore, condition of the catchment can further be improved by adopting more soil and water conservation measures together with restoration of vegetation as evident elsewhere in the world. 
2

3

\section{Figure Caption}

Figure 1 Map of the Upper Mahaweli Catchment (UMC) showing extension of Upper Uma Oya sub-catchment (green in colour).

Figure 2 Land use of the Upper Uma Oya catchment. The map was prepared using Aerial Photographs taken by the Survey Department of Sri Lanka in 1999. Field data were also used in land use classification.

Figure 3 Slope map of the Upper Uma Oya catchment. The map was prepared using Aerial Photographs taken by the Survey Department of Sri Lanka in 1999.

Figure 4 Map showing the spatial distribution of rainfall within the Upper Uma Oya catchment. The map was developed by interpolation of rainfall data of six meteorological stations.

Figure 5 Implemented soil conservation measures in the Upper Uma Oya catchment (A) Drain lines, (B) Check Dams, (C) Gully conservation structures and (D) SALT

Figure 6 (a) Cross sectional view of Upper Uma Oya at the gauging station (06 $54^{\prime} 51^{\prime \prime} \mathrm{N}$ and $80^{\circ} 54^{\prime} 29^{\prime}$ E) installed at Welimada town, (b) Depth-and-width integrated sampling at the river cross section. Sand samples were collected from all the points on each vertical whereas silt and clay samples were taken from all the points except the centre.

Figure 7 Annual wash load (silt plus clay) and sand load transport in the suspended load of the Upper Uma Oya catchment from 1994 to 2005. Note that wash load represents ca. 70$90 \%$ of the suspended load.

Figure 8. Variation of cumulative suspended load (sum of clay, silt and sand) in the Upper Uma Oya catchment with cumulative annual discharge from 1994 to 2005 (a) during the entire year and (b) during high and low rainfall periods. 
1 Figure 9. Diagrams showing (a) the extent of land use on different slope angles and (b) rates

2 of soil loss over different land use types (date from Gunatilake and Vieth, 2000).

3

4

6

7

8

9

10

11

Figure 10.Average monthly rainfall and discharge of the Upper Uma Oya catchment from 1994 to 2005

\section{References}

Bruce-Okine E., and Lal R. 1975, Soil erodibility as determined by raindrop technique, Soil Science, Vol. 119, No. 2, pp. 149-157.

De Silva R. P., and Chandrasekara M. 2002, Impact of Land Use Changes on Hydrological Regime; A case study of Randenigala \& Kotmale Catchments in Sri Lanka, Proceedings of Map Asia 2002 Conference, Bangkok, Thailand.

Diyabalanage, S., 2013. Study the effectiveness of soil conservation in upper Uma oya sub catchment. BSc in Environmental Science and Natural Resource Management Dissertation, Sabaragamuwa University of Sri Lanka, Unpublished.

Ebisemiju F. S. 1988, Gully morphometric controls in a laterite terrain, Guyana, Geo Eco Trop.

Gamage D., and Mohamed A. 1998, Economic and Social Factors affecting land degradation in UMC, Environment action project, Ministry of forestry and environment in Sri Lanka.

Gunatilake H., and Vieth G. 2000, Estimation of on-site cost of soil erosion: A comparison of replacement and productivity change methods. Journal of Soil and Water Conservation, Vol. 55, No. 2, pp.197-204.

Hewavisenthi A. C. D. S. 1997, Management of the Mahaweli, a river in Sri Lanka. Water international, Vol. 22, No. 2, pp. 98-107.

Hewawasam Tilak and Illangasinghe Sadun, 2015, Quantifying sheet erosion in agricultural highlands of Sri Lanka by tracking grain-size distributions, Anthropocene, Vol. 11, pp. 25-34. 
2 Hewawasam T. 2010, Effect of land use in the upper Mahaweli catchment area on erosion, landslides and siltation in hydropower reservoirs of Sri Lanka, Journal of the National

Hewawasam T., von Blanckenburg F., Schaller M., and Kubik P. 2003, Increase of human over natural erosion rates in tropical highlands constrained by cosmogenic nuclides. Geology,

9

Horowitz A. J. 2003, An evaluation of sediment rating curves for estimating suspended sediment concentrations for subsequent flux calculations, Hydrological processes, Vol. 17, No. 17, pp. 3387-3409.

Illangasinghe S. and Hewawasam T. 2015, Introducing surface sampling threshold factor for suspended sedement transport: model development using Sri Lankan tropical highland river basins, Hydrology Research, Vol. 46, No. 1, pp. 136-155.

Jayaweera J. M., De Zoysa M., and Kariyawasam D. 2004, Uma-Oya Upper Watershed Management Project (UWMP) in Sri Lanka: The Impacts at Household Level, Proceedings of Human Dimensions of Family, Farm and Community Forestry International Symposium, Washington, USA, pp. 181-185.

Kahya E. and Kalaycı S. 2004, Trend analysis of streamflow in Turkey, Journal of Hydrology, Vol. 289, No. 1, pp. 128-144.

Kendall M. G. 1975, Rank correlation methods, Charles Griffin, London.

Kirkby M. J., Le Bissonais Y. L., Coulthard T. J., Daroussin J., and McMahon M. D. 2000, The development of land quality indicators for soil degradation by water erosion, Agriculture Ecosystem \& Environment, Vol. 81, No. 2, pp. 125-136.

Krasa, J., Dostal, T., Van Rompaey, A., Vaska, J. \& Vrana, K. 2005. Reservoirs' siltation measurments and sediment transport assessment in the Czech Republic, the Vrchlice catchment study. Catena, 64, 348-362. 
2 Lal, R. 2003. Soil erosion and the global carbon budget. Environment international, 29, 437-

3

4

5

7

8 450.

Pimentel, D. 2001. The limitations of biomass energy. Encyclopedia of physical science and technology, 2, 159-171.

Makadawara S. M. B. 1998, Uma Oya Catchment Conservation: Upper Mahaweli Watershed Management Project, Dam Site, Polgolla, Sri Lanka.

Mann H. B. 1945, Nonparametric tests against trend, Econometrica: Journal of the Econometric Society, Vol. 13, No. 3, pp. 245-259.

Munaweera, D. P. (2013). Personal Communication, Former Director, UWMP.

Olive L., and Rieger, W. 1992, Stream suspended sediment transport monitoring-why, how and what is being measured. Proceedings of the International Symposium on Erosion and Sediment Transport Monitoring Programmes in River Basins, Oslo, Norway, pp. 245-254.

Overall Progress Report, Upper Watershed Management Project, 30, Laxapana Mawatha, Battaramulla, Ministry of Environmental and Natural Resources, (2006).

Pimentel D. 1993, World soil erosion and conservation, Cambridge University Press, Cambridge, UK.

Rajapakse H. A. 1998, Rationalizing Land Use in the Uma Oya Catchment Area. Environment and Forest Conservation Division, Mahaweli Authority of Sri Lanka, Polgolla. Sri Lanka.

Sen P. K. 1968, Estimates of the regression coefficient based on Kendall's tau, Journal of the American Statistical Association, Vol. 63, No. 324, pp. 1379-1389.

Shang P., and Kamae S. 2005, Fractal nature of time series in the sediment transport phenomenon, Chaos, Solitons \& Fractals, Vol. 26, No.3, pp. 997-1007. 
2 Statistical Digest 2013, Ceylon Electricity Board, Colombo, Sri Lanka.

3

4 Syvitski J. P., Morehead M. D., Bahr D. B., and Mulder T. 2000, Estimating fluvial sediment

5 transport: The rating parameters, Water Resources Research Vol. 36, No. 9, pp. 2747-2760.

6

7 Vanacker V., von Blanckenburg F., Govers G., Molina A., Poesen J., Deckers J., and kubik P. 8 2007, Restoring dense vegetation can slow mountain erosion to near natural benchmark 9 levels, Geology, Vol. 35, No. 4, pp. 303-306.

10

11 Walling D., and Fang D. 2003, Recent trends in the suspended sediment loads of the world's 12 rivers, Global and Planetary Change, Vol. 39, No.1, pp. 111-126.

14 Yin, H. \& Li, C. 2001. Human impact on floods and flood disasters on the Yangtze River. 15 Geomorphology, 41, 105-109. 


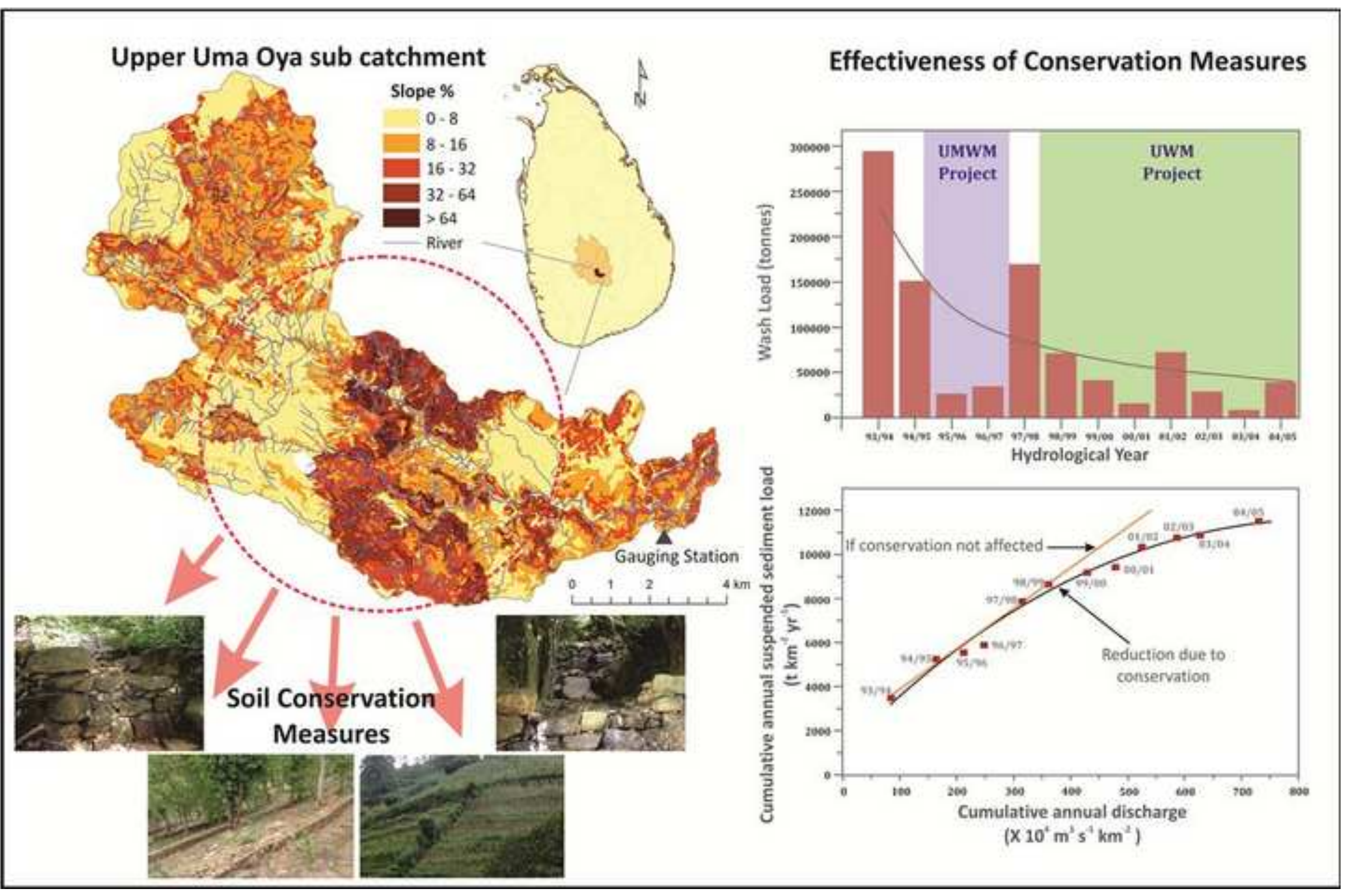




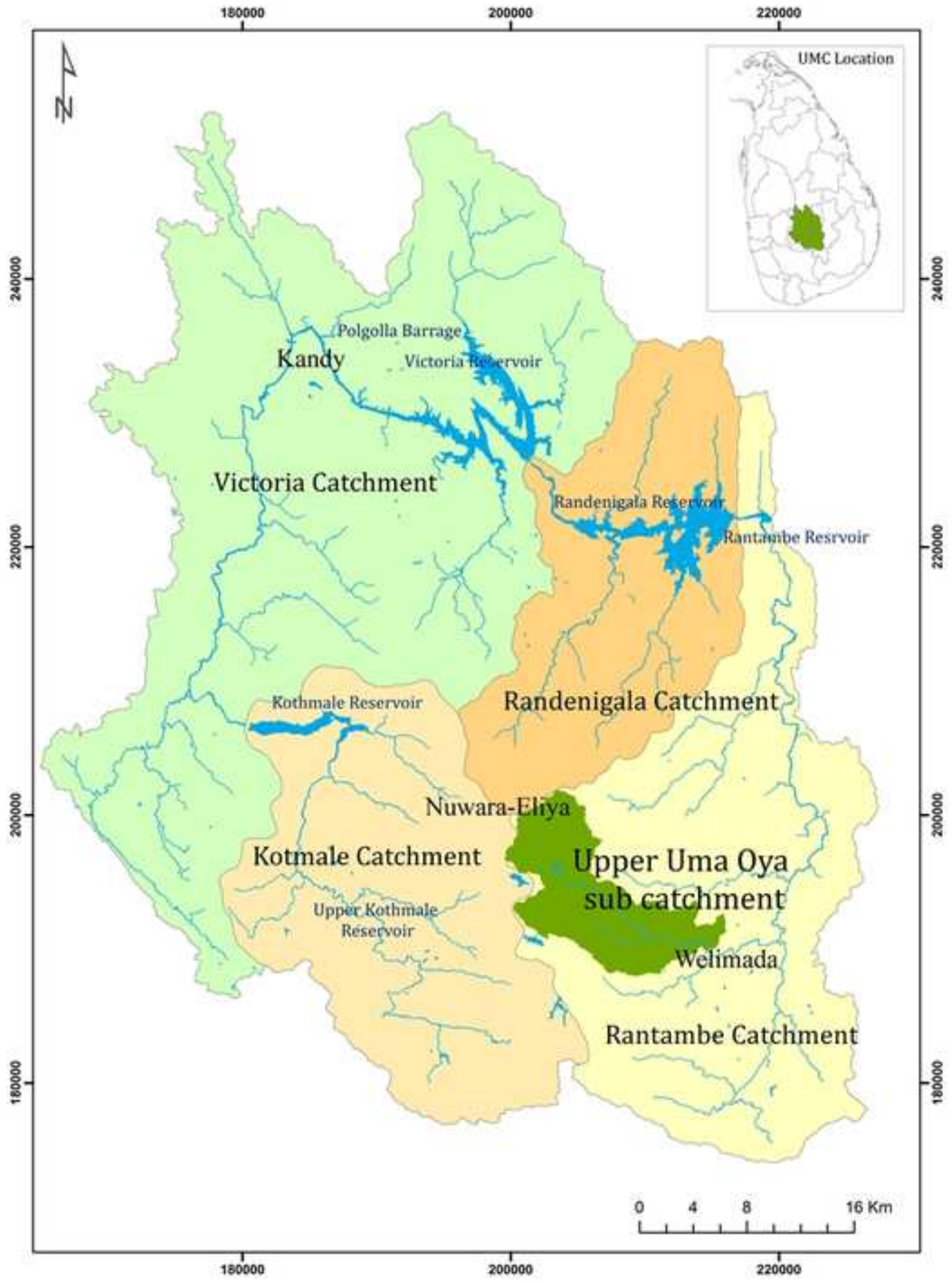




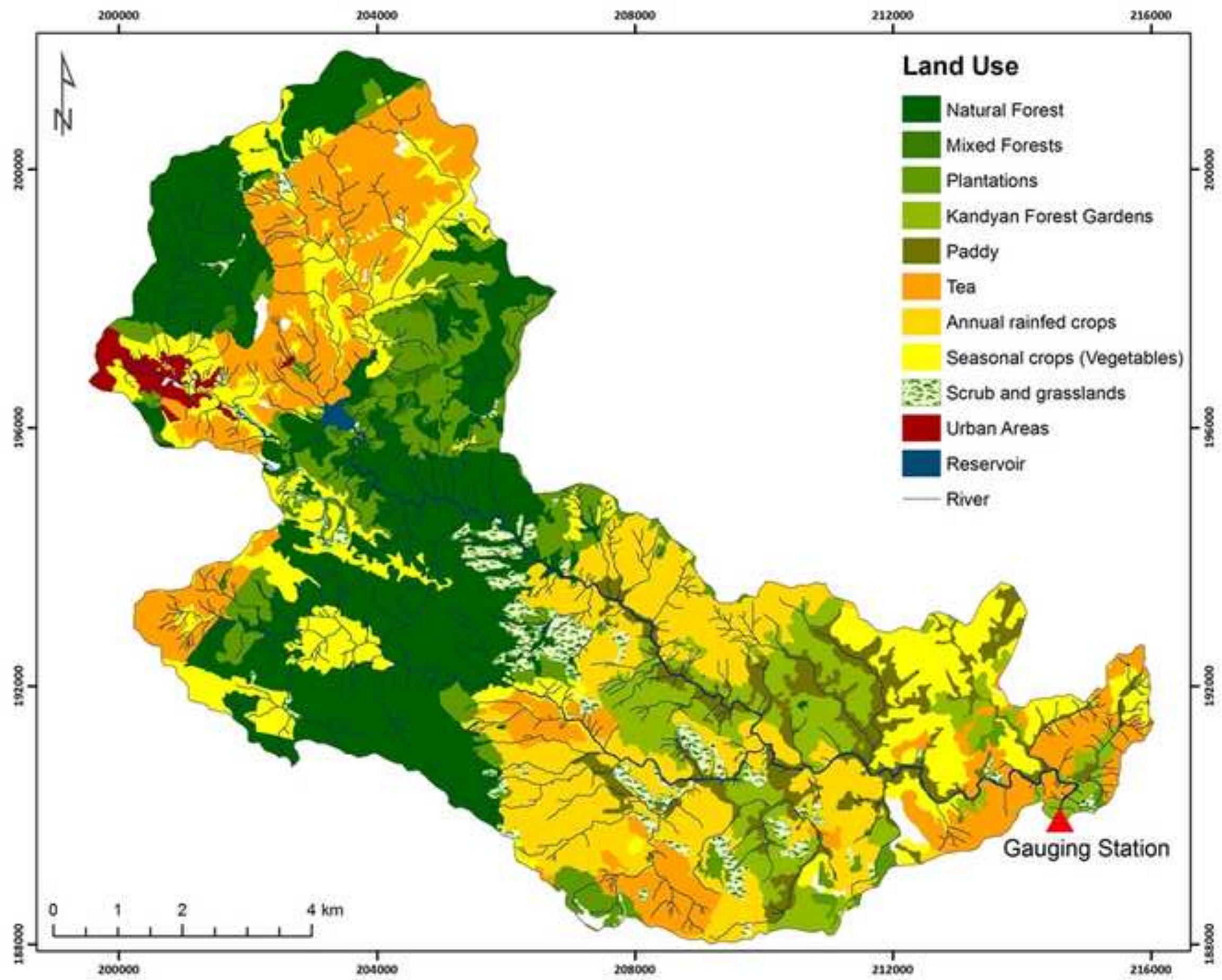




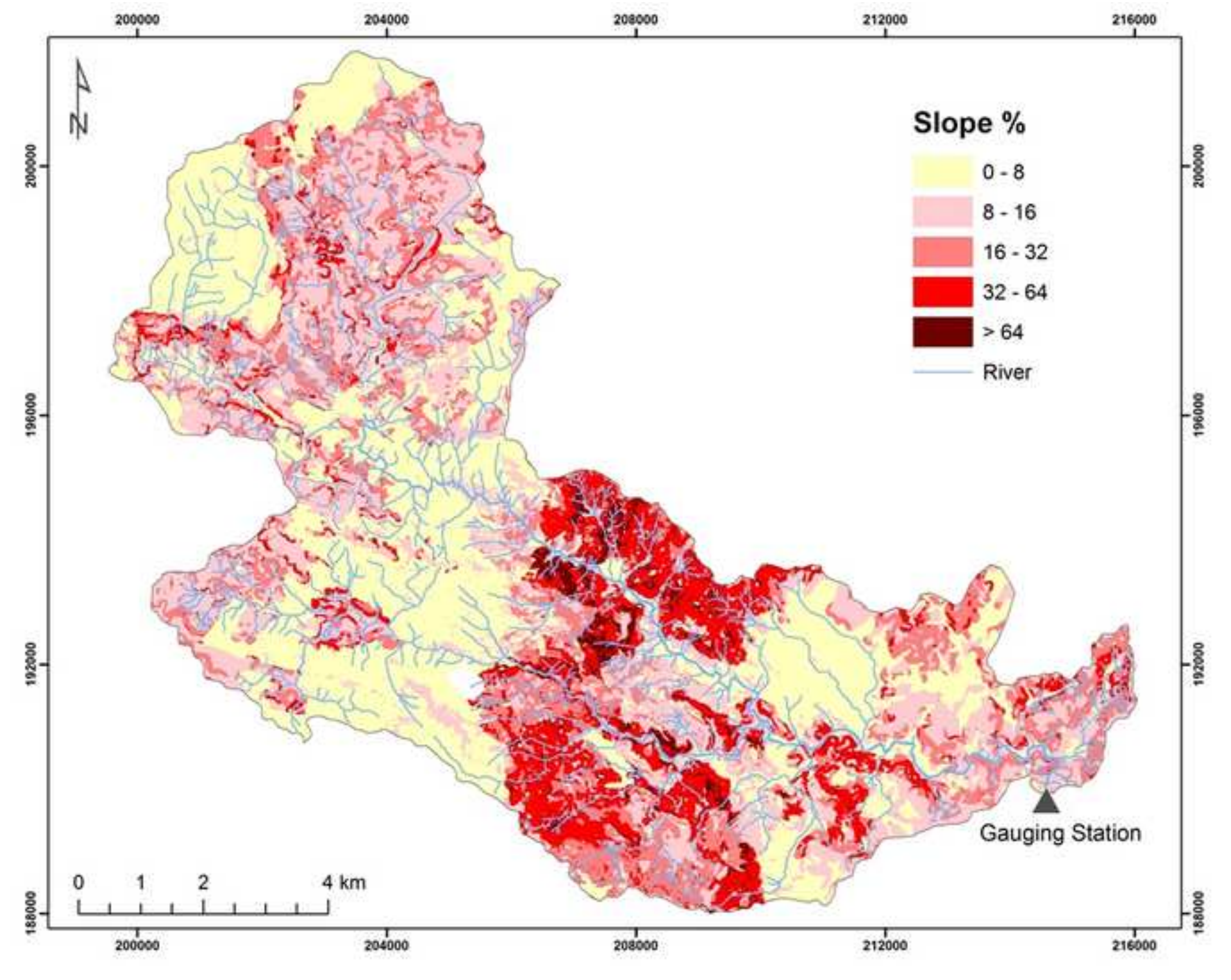

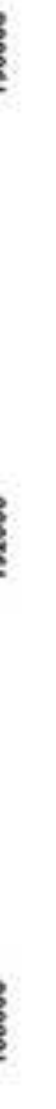




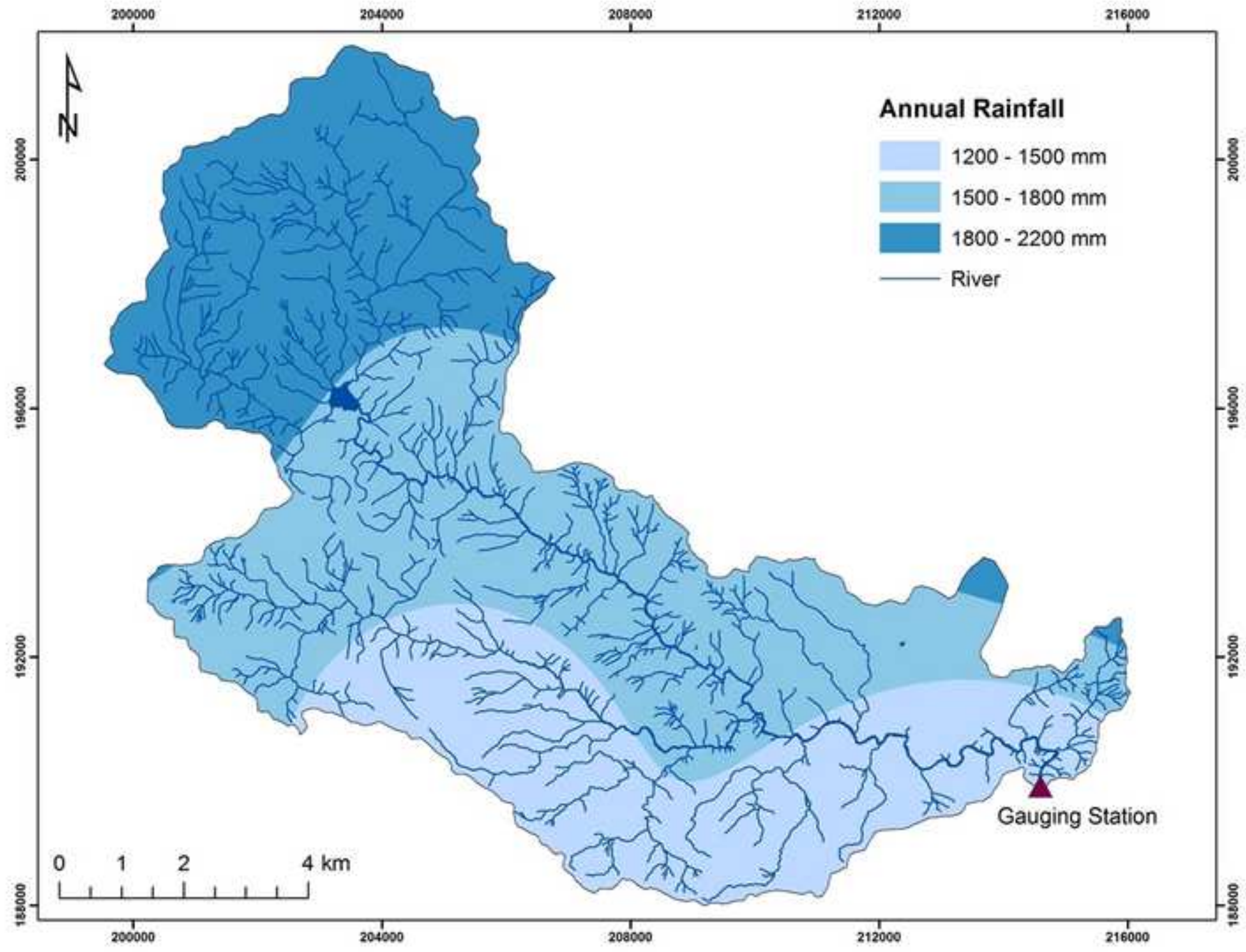



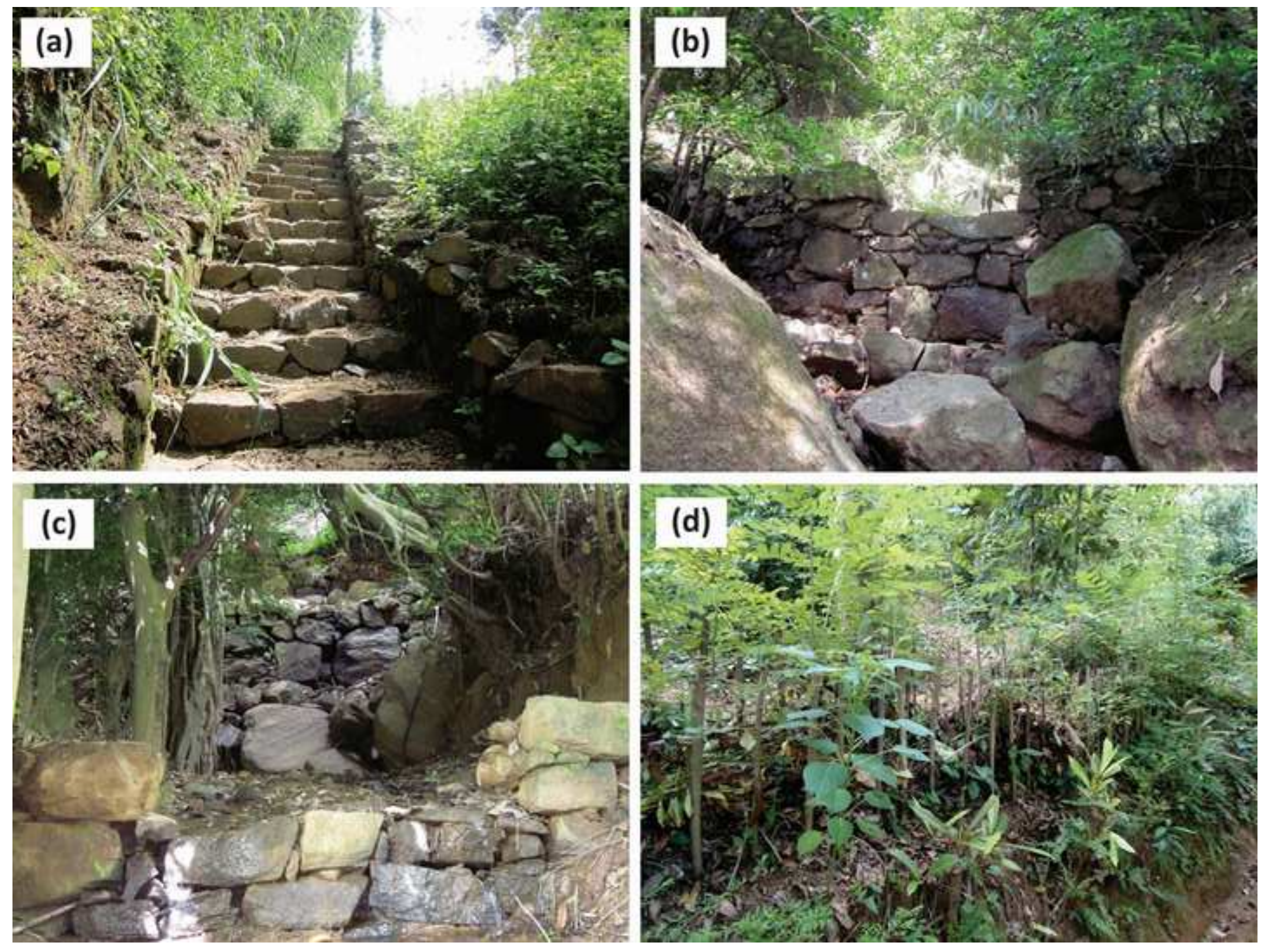

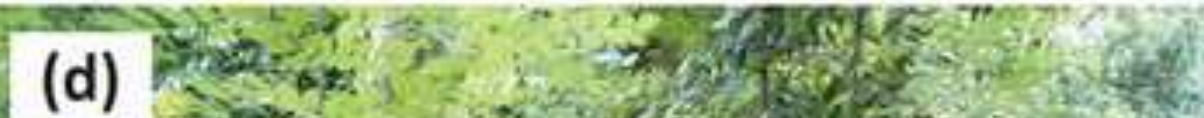

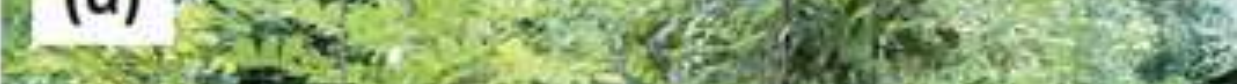

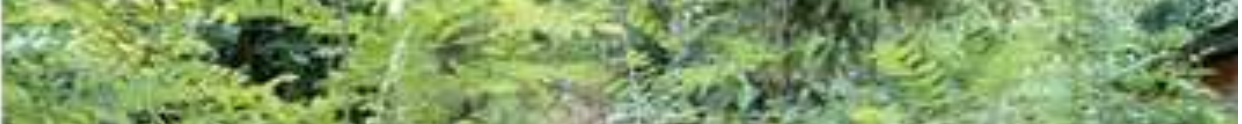

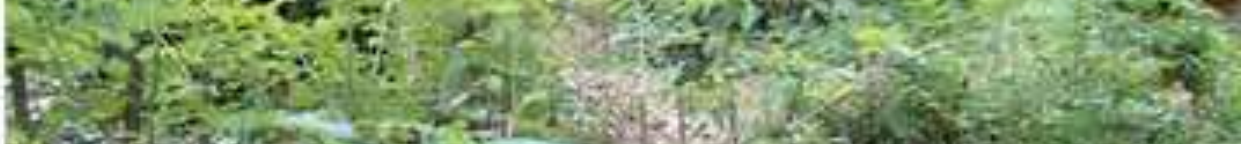
3.

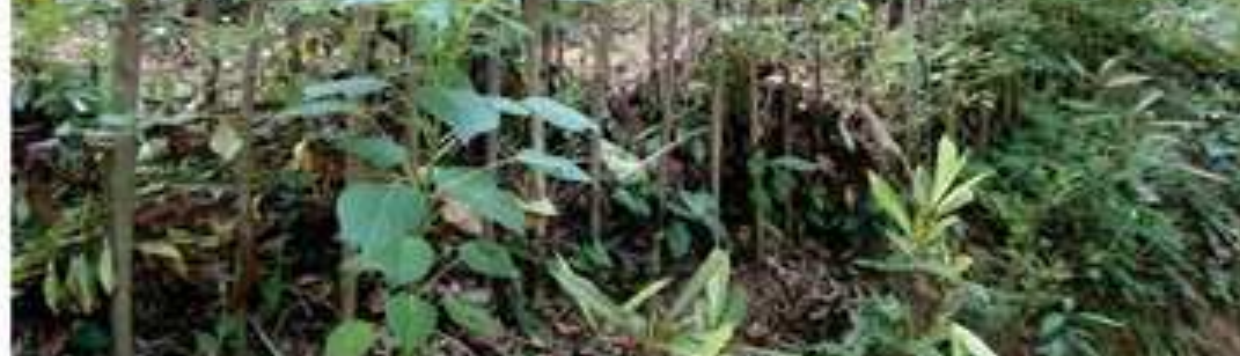
(2)

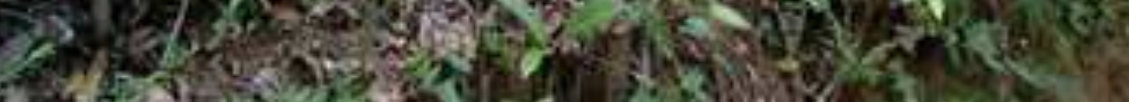

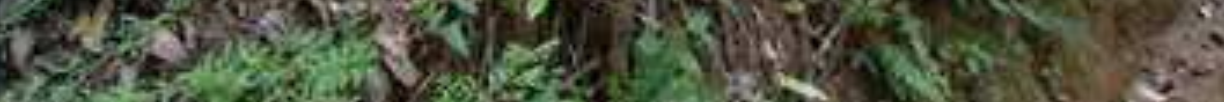



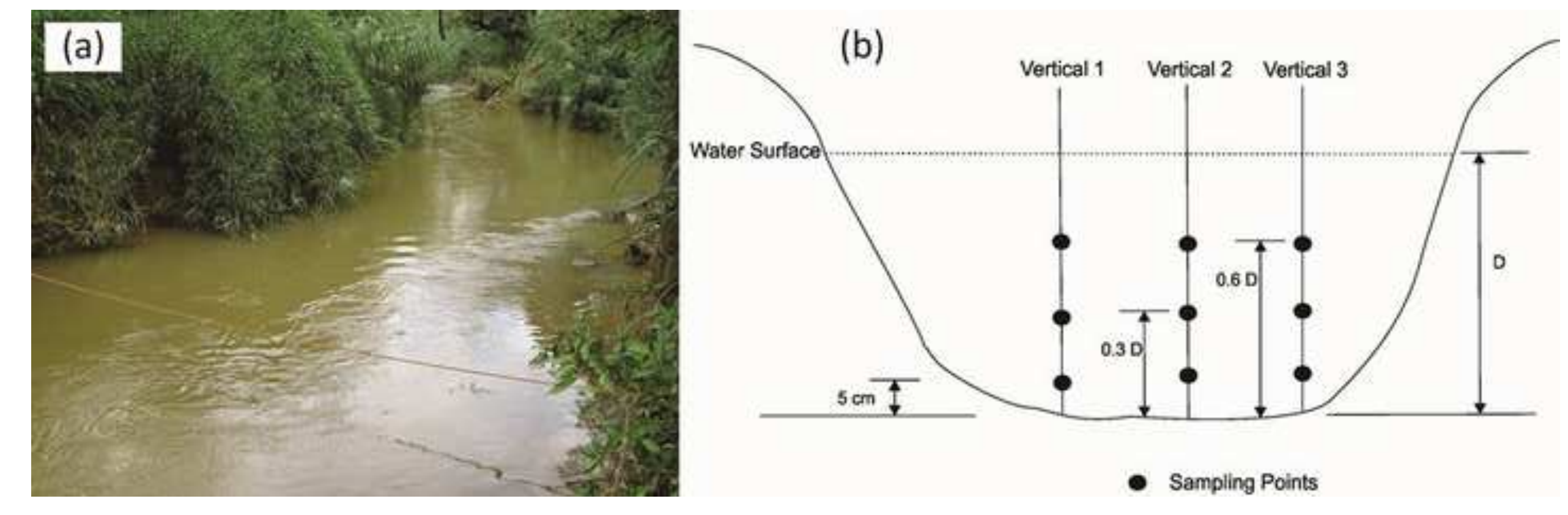

- Sampling Points
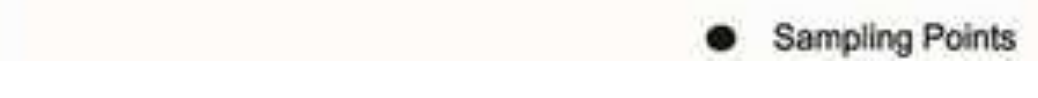


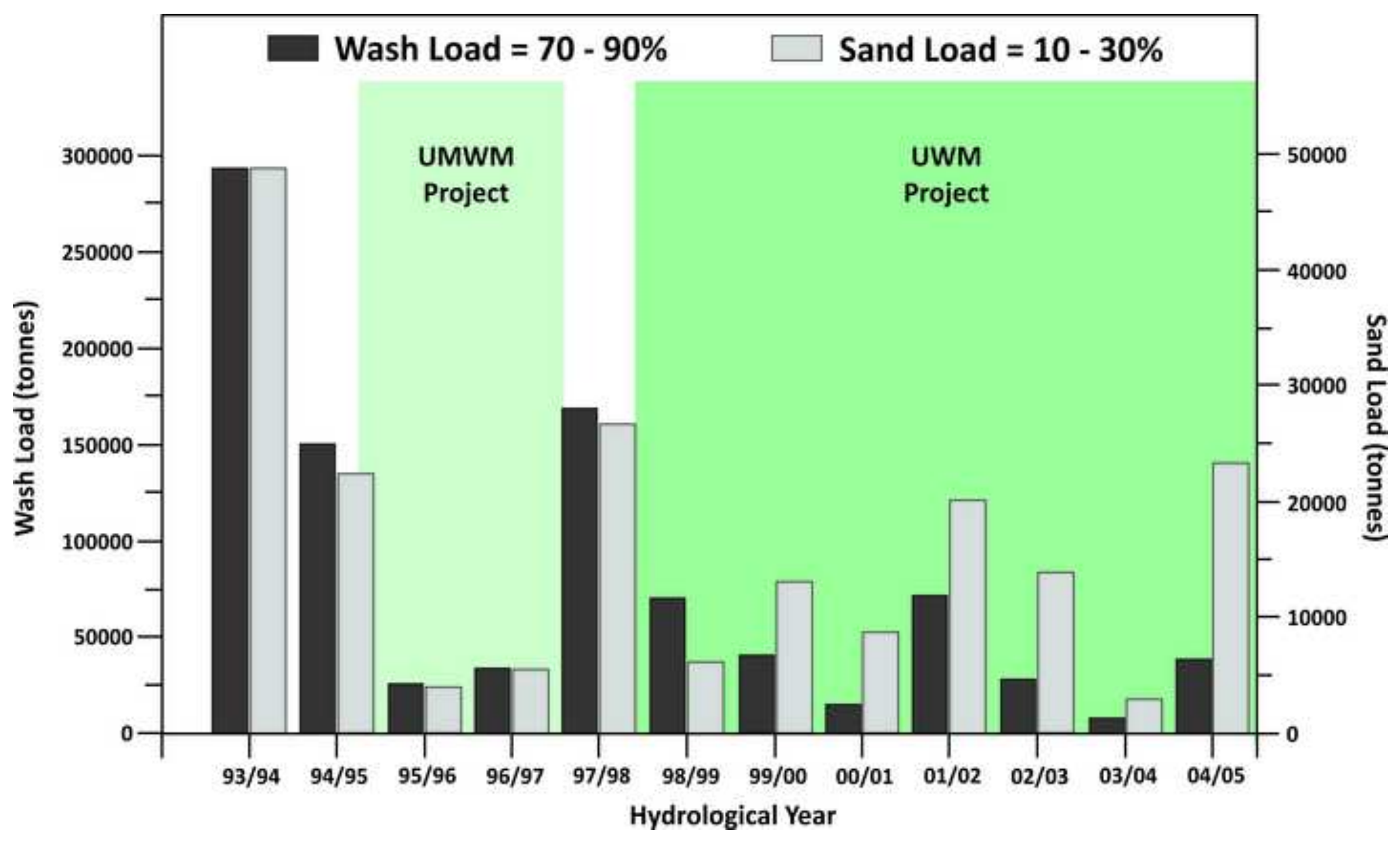



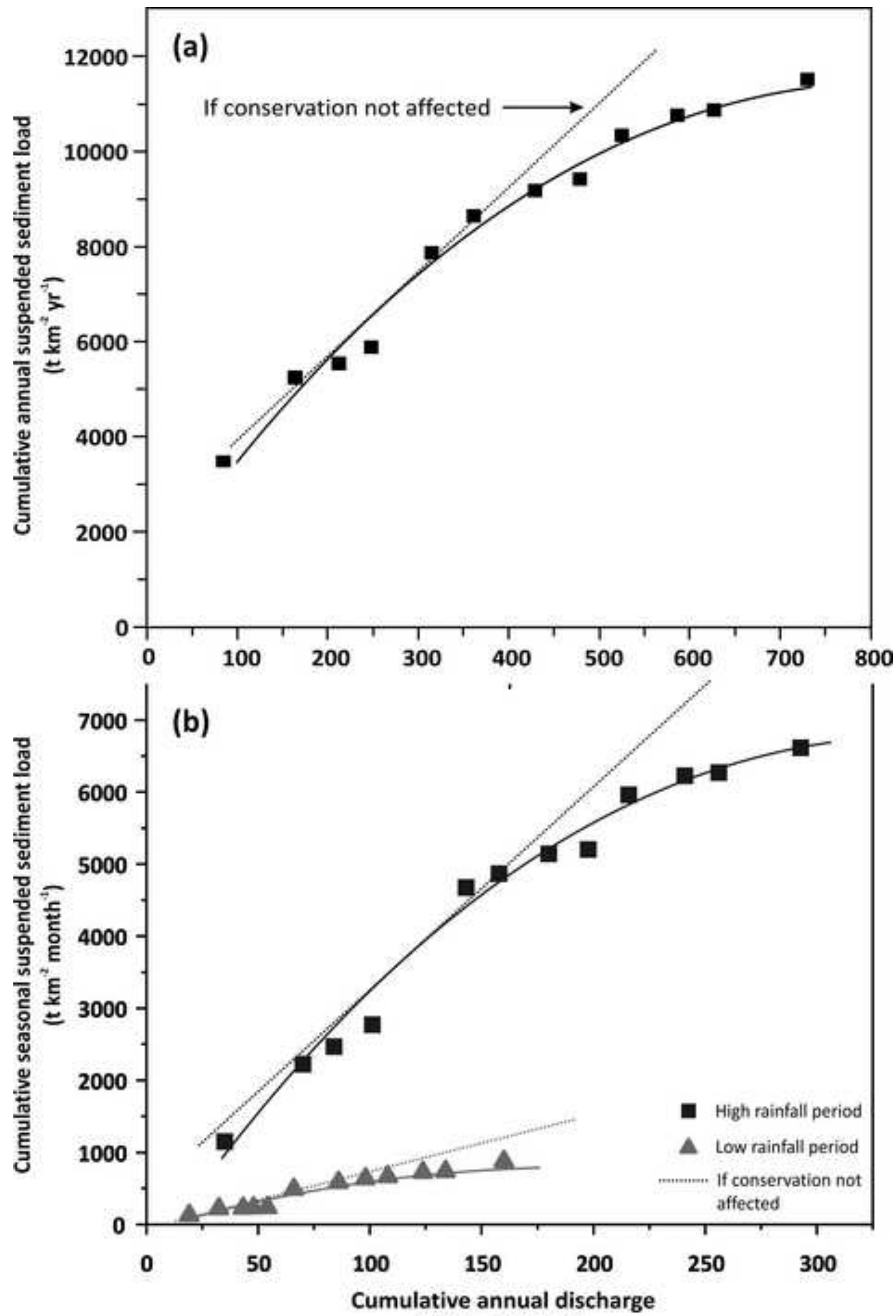

(X $10^{4} \mathrm{~m}^{3} \mathrm{~s}^{-1} \mathrm{~km}^{-2}$ ) 
(a)

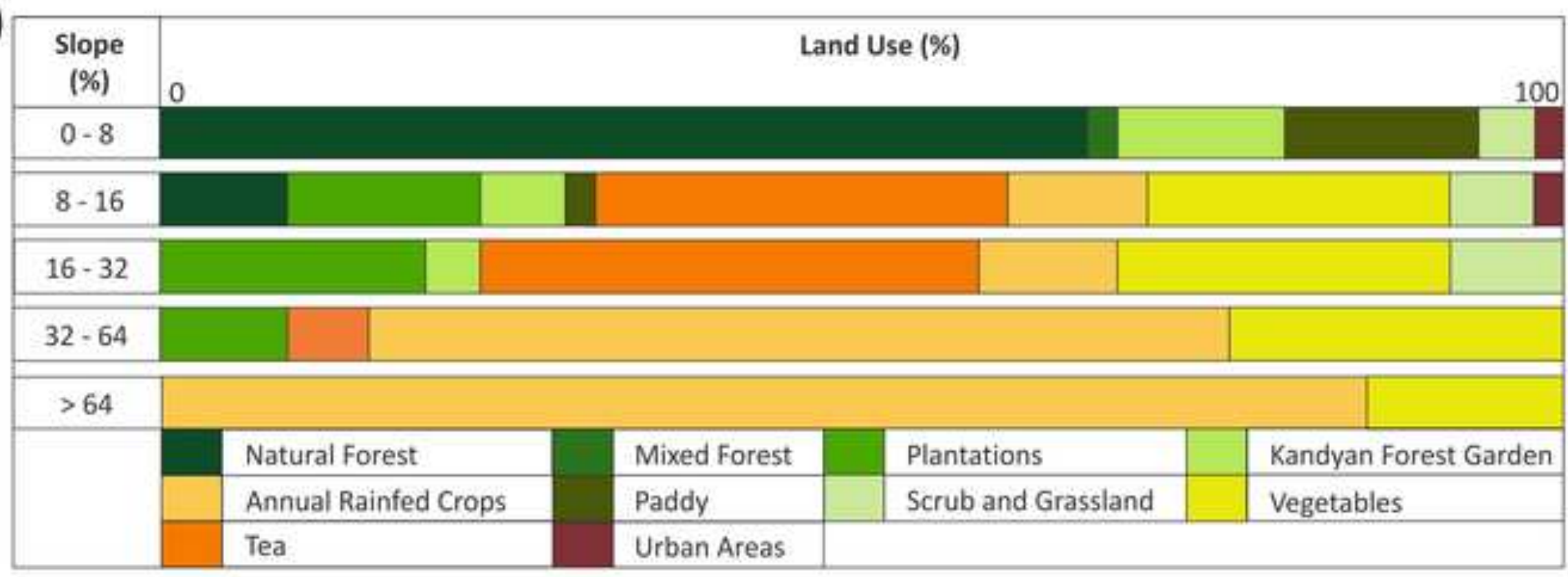

(b)

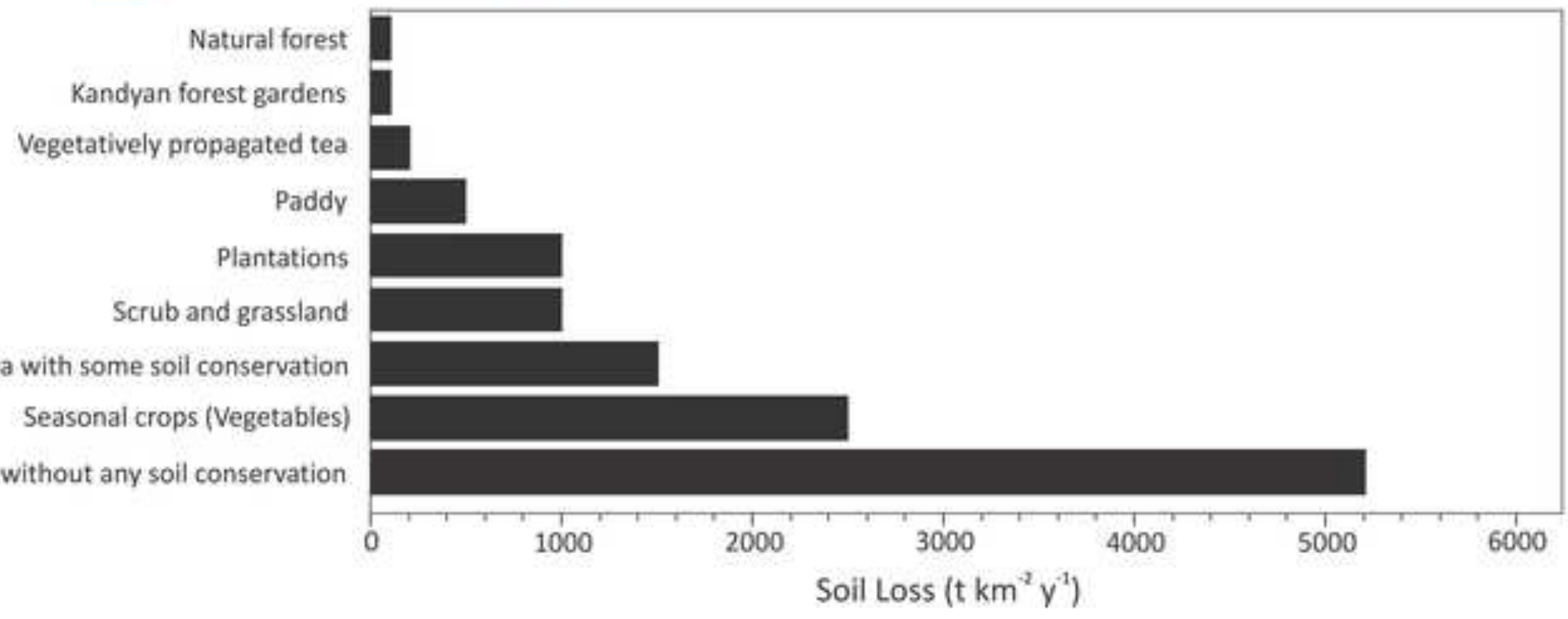

Seedling tea with some soil conservation

Seasonal crops (Vegetables)

Seedling tea without any soil conservation 


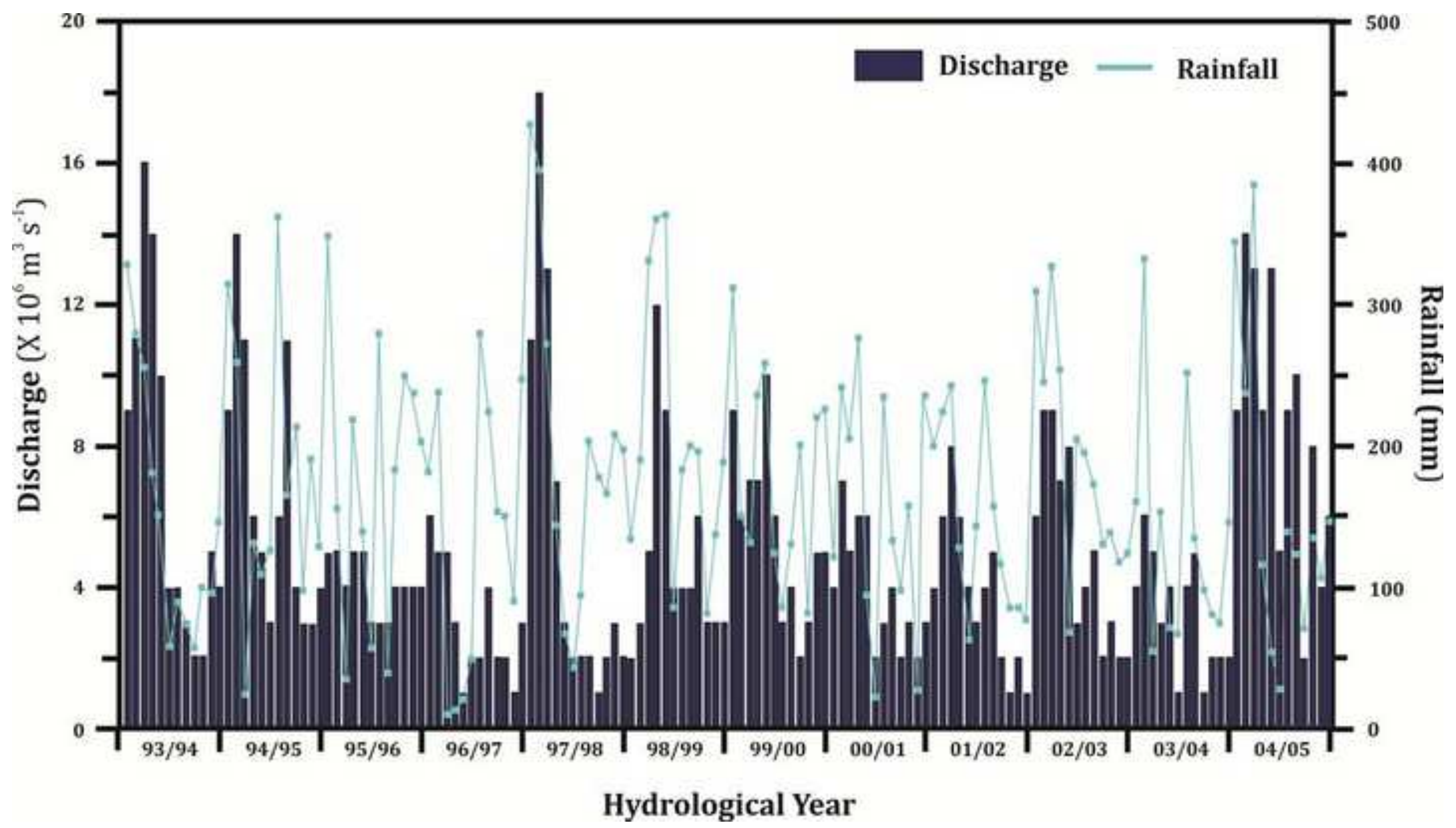

